\title{
Identification of common gene networks responsive to mild hyperthermia in human cancer cells
}

\author{
AYAKO KARIYA $^{2 *}$, YOSHIAKI TABUCHI $^{1 *}$, TATSUYA YUNOKI $^{2}$ and TAKASHI KONDO ${ }^{2}$ \\ ${ }^{1}$ Division of Molecular Genetics Research, Life Science Research Center, ${ }^{2}$ Department of Radiological Sciences, \\ Graduate School of Medicine and Pharmaceutical Sciences, University of Toyama, Toyama 930-0194, Japan
}

Received February 4, 2013; Accepted March 14, 2013

DOI: $10.3892 /$ ijmm.2013.1366

\begin{abstract}
Hyperthermia (HT) has been used as a possible treatment modality for various types of malignant tumors. Due to its pleiotropic effects, its combined use with radiotherapy and/or chemotherapy has proven to be beneficial. However, the molecular mechanisms underling the cellular responses to heat stress remain unclear. Therefore, the aim of this study was to identify common gene expression patterns responsive to mild HT (MHT) in human cancer cells. HeLa human cervical squamous cell carcinoma (SCC) and HSC-3 human oral SCC cells were exposed to $\mathrm{MHT}$ at $41^{\circ} \mathrm{C}$ for $30 \mathrm{~min}$, followed by culture at $37^{\circ} \mathrm{C}$ for $0-24 \mathrm{~h}$. MHT did not affect cell viability or the cell cycle. GeneChip microarray analysis clearly revealed that many probe sets were differentially expressed by a factor of $\geq 1.5$ in both cell lines following exposure to MHT. Of the many
\end{abstract}

Correspondence to: Dr Yoshiaki Tabuchi, Division of Molecular Genetics Research, Life Science Research Center, University of Toyama, 2630 Sugitani, Toyama 930-0194, Japan

E-mail: ytabu@cts.u-toyama.ac.jp

*Contributed equally

Abbreviations: BAG3, BCL2-associated athanogene 3; BCL2, B-cell CLL/lymphoma 2; BCL6, B-cell CLL/lymphoma 6; BHLHE40, basic helix-loop-helix family, member e40; BMP2, bone morphogenetic protein 2; CTGF, connective tissue growth factor; DMEM, Dulbecco's modified Eagle's medium; DNAJB1, DnaJ (Hsp40) homolog, subfamily B, member 1; DNAJB4 DnaJ (Hsp40) homolog, subfamily B, member 4; DUSP1, dual specificity phosphatase 1 ; EDN1, endothelin 1; ERG1, early growth response 1; FBS, fetal bovine serum; GAPDH, glyceraldehyde-3-phosphate dehydrogenase; HSF1, heat shock transcription factor 1; HSP, heat shock protein; HSPA1A/B, heat shock $70 \mathrm{kDa}$ protein $1 \mathrm{~A} / \mathrm{B}$; HSPA1H, heat shock 105/110 kDa protein; HSPA1L, heat shock $70 \mathrm{kDa}$ protein 1-like; HSPA4L, heat shock protein 4 like; HSPA6, heat shock $70 \mathrm{kDa}$ protein 6 (HSP70B'); HSPB1, heat shock $27 \mathrm{kDa}$ protein 1; HT, hyperthermia; MHT, mild hyperthermia; MXD1, MAX dimerization protein 1; PI, propidium iodide; qPCR, quantitative polymerase chain reaction; SCC, squamous cell carcinoma; SOCS3, suppressor of cytokine signaling 3; SOX6, SRY (sex determining region Y)-box 6

Key words: mild hyperthermia, microarray, gene network, cancer cells differentially expressed probe sets, 114 genes were found to be commonly upregulated in both HeLa and HSC-3 cells, and two significant gene networks were obtained from the commonly upregulated genes. Gene network A included several heat shock proteins, as well as BCL2-associated athanogene 3 (BAG3), and was found to be mainly associated with the biological functions of cellular function and maintenance. Gene network B included several anti-cell death genes, such as early growth response 1 (EGR1) and endothelin 1 (EDN1) and was found to be associated with the biological functions of cell death and survival. Real-time quantitative polymerase chain reaction demonstrated that the gene expression patterns of the 12 genes selected were consistent with the microarray data in four cancer cell lines. These findings may provide further insight into the detailed molecular mechanisms of the MHT response in cancer cells.

\section{Introduction}

Hyperthermia (HT) is a well-established treatment modality that is used alone or in combination with other therapies, such as radiotherapy and chemotherapy, for the treatment of a variety of tumors (1). It has been indicated that only cancer cells treated at temperatures $>42.5^{\circ} \mathrm{C}$, the inflection point of HT, will undergo cell death as the temperature increases, whereas temperatures in the mild hyperthermia (MHT) range $<42.5^{\circ} \mathrm{C}$ induce little or no cytotoxicity (2). However, HT monotherapy, maintaining a cancer temperature $>42.5^{\circ} \mathrm{C}$ for direct cytotoxicity, has been associated with higher toxicity and less efficacy against cancer. Therefore, MHT, in combination with radiotherapy and/or chemotherapy, has been used for the treatment of various types of cancer, and its antitumor effects have been verified by several clinical trials (3-7). In addition, recent studies have demonstrated that an antitumor immune system including heat shock protein (HSP) chaperone tumor antigens may be effective as a cancer immunotherapy based on MHT $(8,9)$.

The heat shock response, a universal cellular response to elevated temperatures, is a very important cellular event for cell adaptation. It has been well recognized that heat elicits a wide variety of stress responses, such as the induction of HSPs, DNA and RNA damage, protein aggregation, cell growth arrest and cell death (10-12). HSPs, which are are induced by heat in particular, behave as strong cytoprotective molecules preventing cell death (12) and participate in thermoresistance $(13,14)$. 
Although heat affects several biological processes, the overall responses to heat in mammalian cells are not yet completely understood. To this end, a number of studies have found that the most effective approach for investigating heat responses is to use global-scale microarrays and bioinformatics tools. Several genes and biological functions in a wide variety of cell types affected by heat stress have thus been reported (15-27).

In the present study, in order to further elucidate the molecular mechanisms underlying cellular responses to MHT in cancer cells, we compared the gene expression profiles by using high-density oligonucleotide microarrays and computational gene expression analysis tools in two human cancer cell lines, HeLa cervical squamous cell carcinoma (SCC) and HSC-3 oral SCC cells, exposed to MHT at $41^{\circ} \mathrm{C}$. Moreover, common expression patterns responsive to $\mathrm{MHT}$ in two other human cell lines, MCF-7 breast adenocarcinoma and HO-1-N-1 oral SCC, in addition to the HeLa and HSC-3 cell lines were determined by real-time quantitative polymerase chain reaction (qPCR).

\section{Materials and methods}

Cell culture. The human oral SCC cell lines, HSC-3 (derived from tongue carcinoma) and HO-1-N-1 (derived from buccal mucosa) were obtained from the Human Science Research Resources Bank of the Japan Health Sciences Foundation (Tokyo, Japan). The human cervical SCC cell line, HeLa, and the breast adenocarcinoma cell line, MCF-7, were provided by the RIKEN BioResource Center through the National BioResource Project of the Ministry of Education, Culture, Sports, Science and Technology (MEXT) (Tsukuba, Japan). The HeLa and MCF-7 cells were cultured in Dulbecco's modified Eagle's medium (DMEM; Life Technologies Co., Grand Island, NY, USA) supplemented with $10 \%$ fetal bovine serum (FBS). The HSC-3 and HO-1-N-1 cells were cultured in Eagle's minimum Essential medium (Wako Pure Chemical Industries, Ltd., Osaka, Japan) and DMEM/Ham's F-12 medium (Wako Pure Chemical Industries, Ltd.), respectively, each supplemented with $10 \%$ FBS. The cells were maintained at $37^{\circ} \mathrm{C}$ in a humidified atmosphere with $5 \% \mathrm{CO}_{2}$ and $95 \%$ air.

Exposure to MHT. The cells were exposed to MHT by immersing plastic culture vessels containing the attached cells in a water bath at $41^{\circ} \mathrm{C}$ for $30 \mathrm{~min}$. Following exposure to heat, the cells were incubated for $0-24 \mathrm{~h}$ at $37^{\circ} \mathrm{C}$.

Analyses of cell viability and cell cycle. For cell viability, the trypan blue dye exclusion test was performed. The cells excluding the dye were counted using a hematocytometer. For the cell cycle, cells were fixed with $70 \%$ ice-cold ethanol and then treated with RNase A and propidium iodide (PI). The samples were run on an Epics XL flow cytometer (Beckman Coulter, Fullerton, CA, USA) as previously described (28).

RNA isolation. Total RNA was extracted from the cells using an RNeasy Total RNA Extraction kit (Qiagen, Valencia, CA, USA) along with On-Column DNase I treatment. The RNA concentration was measured using a Nanodrop spectrophotometer (Thermo Fisher Scientific Inc., Waltham, MA, USA). RNA integrity was determined using a Bioanalyzer 2100 (Agilent Technologies, Inc., Santa Clara, CA, USA). RNA samples with RNA integrity number (RIN) values $>9.5$ were considered acceptable.

Global-scale gene expression analysis. Global-scale gene expression analysis was performed using a GeneChip ${ }^{\circledR}$ microarray system with a Human Genome U133-plus 2.0 array, which was spotted with 54,675 probe sets (Affymetrix Inc., Santa Clara, CA, USA) according to the manufacturer's instructions. In brief, $500 \mathrm{ng}$ of total RNA were used to synthesize cRNA with a GeneChip ${ }^{\circledR}$ 3' IVT Express kit (Affymetrix Inc.). Following fragmentation, biotin-labeled cRNA was hybridized to the array at $45^{\circ} \mathrm{C}$ for $16 \mathrm{~h}$. The arrays were washed, stained with streptavidin-phycoerythrin, and scanned using a probe array scanner. The obtained hybridization intensity data were analyzed using GeneSpring ${ }^{\circledR}$ GX (Agilent Technologies Inc.) to extract the significant genes. To examine gene ontology, including biological processes, cellular components, molecular functions and gene networks, the obtained data were analyzed using Ingenuity ${ }^{\circledR}$ Pathway Analysis tools (Ingenuity Systems Inc., Mountain View, CA, USA), a web-delivered application that enables the identification, visualization and investigation of molecular interaction networks in gene expression data $(29,30)$.

Real-time qPCR assay. The reverse transcriptase reaction was carried out with total RNA using a random 6-mer and an oligo(dT) primer. Real-time qPCR was performed on an Mx3005P real-time PCR system (Agilent Technologies Inc.) using SYBR PreMix ExTaq (Takara Bio Inc., Shiga, Japan) or Premix Ex Taq (for the use of TaqMan probes; Takara Bio Inc.). The specific primer and probe sequences for B-cell CLL/ lymphoma 2 (BCL2)-associated athanogene 3 (BAG3), B-cell CLL/lymphoma 6 (BCL6), bone morphogenetic protein 2 (BMP2), connective tissue growth factor (CTGF), DnaJ (Hsp40) homolog, subfamily B, member 1 (DNAJB1), endothelin 1 (EDN1), early growth response 1 (ERG1), glyceraldehyde3-phosphate dehydrogenase (GAPDH), heat shock $70 \mathrm{kDa}$ protein 1A/B (HSPA1A/B), heat shock 105/110 kDa protein (HSPA1H), heat shock $70 \mathrm{kDa}$ protein 6 (HSP70B') (HSPA6), MAX dimerization protein 1 (MXD1) and suppressor of cytokine signaling 3 (SOCS3) are listed in Table I. GAPDH was used as a control for normalization.

Statistical analysis. Data are presented as the means \pm SD. Differences between pairs of data sets were analyzed using the Student's t-test, with values of $\mathrm{P}<0.05$ considered to indicate statistically significant differences.

\section{Results}

Effects of MHT on cell viability and the cell cycle in cancer cell lines. We used a trypan blue dye exclusion test to assess cell viability. Fig. 1A and B indicate the number of HeLa and HSC-3 cells following exposure to $\mathrm{MHT}$ at $41^{\circ} \mathrm{C}$ for $30 \mathrm{~min}$ followed by culture at $37^{\circ} \mathrm{C}$ for $24 \mathrm{~h}$. MHT did not inhibit cell viability compared to the control $\left(37^{\circ} \mathrm{C}\right.$ treatment) in either cell line. Moreover, the cell cycle distribution was monitored by PI staining with flow cytometry. The percentages of control HeLa and HSC-3 cells in the G0/G1, S and G2/M phase were $26.9 \pm 4.8,18.5 \pm 3.3$ and $52.3 \pm 1.2 \%$ for the HeLa cells and $17.5 \pm 4.2,19.3 \pm 2.5$ and $62.2 \pm 3.4 \%$ for the HSC-3 cells 
Table I. Nucleotide sequences of primers and TaqMan probes for target genes.

\begin{tabular}{|c|c|c|c|}
\hline Gene & Orientation & Nucleotide sequence $\left(5^{\prime}-3^{\prime}\right)$ & GenBank accession no. \\
\hline BAG3 & $\begin{array}{l}\text { Sense } \\
\text { Antisense }\end{array}$ & $\begin{array}{l}\text { CGACCAGGCTACATTCCCAT } \\
\text { TCTGGCTGAGTGGTTTCTGG }\end{array}$ & NM_004281 \\
\hline BCL6 & $\begin{array}{l}\text { Sense } \\
\text { Antisense }\end{array}$ & $\begin{array}{l}\text { AATCGTCTCCGGAGTCGAGACA } \\
\text { TGATGTTGCCCTCCCGCAAA }\end{array}$ & NM_002357 \\
\hline BMP2 & $\begin{array}{l}\text { Sense } \\
\text { Antisense }\end{array}$ & $\begin{array}{l}\text { ATGCTGTGTCCCGACAGAAC } \\
\text { AACCCTCCACAACCATGTCC }\end{array}$ & NM_001200 \\
\hline CTGF & $\begin{array}{l}\text { Sense } \\
\text { Antisense }\end{array}$ & $\begin{array}{l}\text { CTGCAGGCTAGAGAAGCAGA } \\
\text { CCGTCGGTACATACTCCACA }\end{array}$ & NM_001901 \\
\hline DNAJB1 & $\begin{array}{l}\text { Sense } \\
\text { Antisense }\end{array}$ & $\begin{array}{l}\text { ACCCGGACAAGAACAAGGAG } \\
\text { GCCACCGAAGAACTCAGCAA }\end{array}$ & NM_006145 \\
\hline EDN1 & $\begin{array}{l}\text { Sense } \\
\text { Antisense }\end{array}$ & $\begin{array}{l}\text { CTTGCCAAGGAGCTCCAGAA } \\
\text { GGCTTCCAAGTCCATACGGAA }\end{array}$ & NM_001955 \\
\hline HSPA1A/B & $\begin{array}{l}\text { Sense } \\
\text { Antisense }\end{array}$ & $\begin{array}{l}\text { AGGTGCAGGTGAGCTACAAG } \\
\text { ATGATCCGCAGCACGTTGAG }\end{array}$ & NM_005346 \\
\hline HSPH1 & $\begin{array}{l}\text { Sense } \\
\text { Antisense }\end{array}$ & $\begin{array}{l}\text { ACCATGCTGCTCCTTTCTCC } \\
\text { CTGGGTTTTCTGGTGGTCTC }\end{array}$ & NM_006644 \\
\hline HSPA6 & $\begin{array}{l}\text { Sense } \\
\text { Antisense }\end{array}$ & $\begin{array}{l}\text { GGCCATGACCAAGGACAACA } \\
\text { AАCCATCСТСТCСАССТССТ }\end{array}$ & NM_002155 \\
\hline MXD1 & $\begin{array}{l}\text { Sense } \\
\text { Antisense }\end{array}$ & $\begin{array}{l}\text { AGACGGGCTCATCTTCGCTT } \\
\text { GCTGAAGCTGGTCGATTTGGTG }\end{array}$ & NM_002357 \\
\hline SOCS3 & $\begin{array}{l}\text { Sense } \\
\text { Antisense }\end{array}$ & $\begin{array}{l}\text { TCTGTCGGAAGACCGTCAAC } \\
\text { TAAAGCGGGGCATCGTACTG }\end{array}$ & NM_003955 \\
\hline EGR1 & $\begin{array}{l}\text { Sense } \\
\text { Antisense } \\
\text { Probe }\end{array}$ & $\begin{array}{l}\text { GGAGCAAAATAAGGAAGAG } \\
\text { GAGAGTTCAGATTTTGTTTTAG } \\
\text { FAM-AGCTGAGCTTCGGTTCTCCA-TAMRA }\end{array}$ & NM_001964 \\
\hline GAPDH & $\begin{array}{l}\text { Sense } \\
\text { Antisense } \\
\text { Probe }\end{array}$ & $\begin{array}{l}\text { AAGGACTCATGACCACAGTCCAT } \\
\text { CCATCACGCCACAGTTTCC } \\
\text { FAM-CCATCACTGCCACCCAGAAGACTGTG-TAMRA }\end{array}$ & NM_002046 \\
\hline
\end{tabular}

BAG3, BCL2-associated athanogene 3; BCL6, B-cell CLL/lymphoma 6; BMP2, bone morphogenetic protein 2; CTGF, connective tissue growth factor; DNAJB1, DnaJ (Hsp40) homolog, subfamily B, member 1; EDN1, endothelin 1; HSPA1A/B, heat shock $70 \mathrm{kDa}$ protein 1A/B; HSPA6, heat shock $70 \mathrm{kDa}$ protein 6 (HSP70B'); MXD1, MAX dimerization protein ; SOCS3, suppressor of cytokine signaling 3; EGR1, early growth response 1; GAPDH, glyceraldehyde-3-phosphate dehydrogenase.

(means \pm SD), respectively. Changes in cell cycle distribution were not observed in the cells exposed to MHT (Fig. 1C and D). Exposure to $\mathrm{MHT}$ at $41^{\circ} \mathrm{C}$ for $30 \mathrm{~min}$ did not affect cell viability or the cell cycle distribution in the other cancer cell lines, MCF-7 and HO-1-N-1 (data not shown). These data demonstrated that the cells exposed to MHT at $41^{\circ} \mathrm{C}$ for $30 \mathrm{~min}$ did not undergo cell damage and cell cycle arrest.

Global-scale gene expression analysis. Global-scale gene expression analysis was performed using a GeneChip microarray system and GeneSpring software. Of the 54,675 probe sets analyzed, many probe sets that were differentially expressed by $\geq 1.5$-fold were detected. We identified 1,053 and 1,278 upregulated, and 701 and 673 downregulated probe sets in the HeLa and HSC-3 cells exposed to MHT at $41^{\circ} \mathrm{C}$ for
$30 \mathrm{~min}$, respectively. Fig. 2 demonstrates the time course of changes in gene expression. In all, 248 and 52 probe sets were also found to be commonly upregulated and downregulated in these respective cell lines (Fig. 2). The complete lists of genes from the HeLa and HSC-3 cell samples have been deposited in the Gene Expression Omnibus (GEO), a public database (accession numbers: GSE43701 and GSE43862).

Identification of biological functions and gene networks. To identify the biological functions and gene networks in the differentially expressed probe sets in the HeLa and HSC-3 cells exposed to MHT, either functional category or gene network analysis was conducted by use of the Ingenuity Pathways Knowledge Base. We identified several functionally annotated genes: 494 and 637 upregulated genes, and 303 and 330 down- 
Table II. Top three biological functions.

Name

P-value

Numbers of molecules

HeLa upregulated genes (494) ${ }^{\mathrm{a}}$

Cell death and survival

3.34E-05-3.39E-02

224

Gene expression

4.92E-05-3.39E-02

169

Cellular development

2.89E-04-3.39E-02

202

HeLa downregulated genes $(303)^{\mathrm{a}}$

Gene expression

6.21E-06-3.57E-02

140

Cellular assembly and organization

$1.00 \mathrm{E}-04-3.57 \mathrm{E}-02$

90

Cellular function and maintenance

$1.00 \mathrm{E}-04-3.57 \mathrm{E}-02$

80

HSC-3 upregulated genes (637) ${ }^{\mathrm{a}}$

Cell death and survival

2.92E-13-2.85E-03

292

Gene expression

3.32E-13-2.71E-03

248

Cellular growth and proliferation

4.54E-10-2.99E-03

299

HSC-3 downregulated genes (330) ${ }^{\mathrm{a}}$

Cell cycle

3.44E-06-3.24E-02

102

3.31E-05-3.25E-02

148

Cell death and survival

9.25E-05-3.26E-02

111

Commonly upregulated genes (114) ${ }^{\mathrm{a}}$

Cellular function and maintenance

2.21E-07-1.89E-02

48

Cell death and survival

2.46E-06-2.01E-02

60

Cellular movement

2.97E-05-2.02E-02

40

Commonly downregulated genes (35) ${ }^{\mathrm{a}}$

Cell cycle

9.35E-05-4.86E-02

48

Cell death and survival

$6.09 \mathrm{E}-04-4.56 \mathrm{E}-02$

60

Gene expression

6.17E-04-4.86E-02

40

${ }^{\mathrm{a} N u m b e r s}$ of functionally annotated genes.
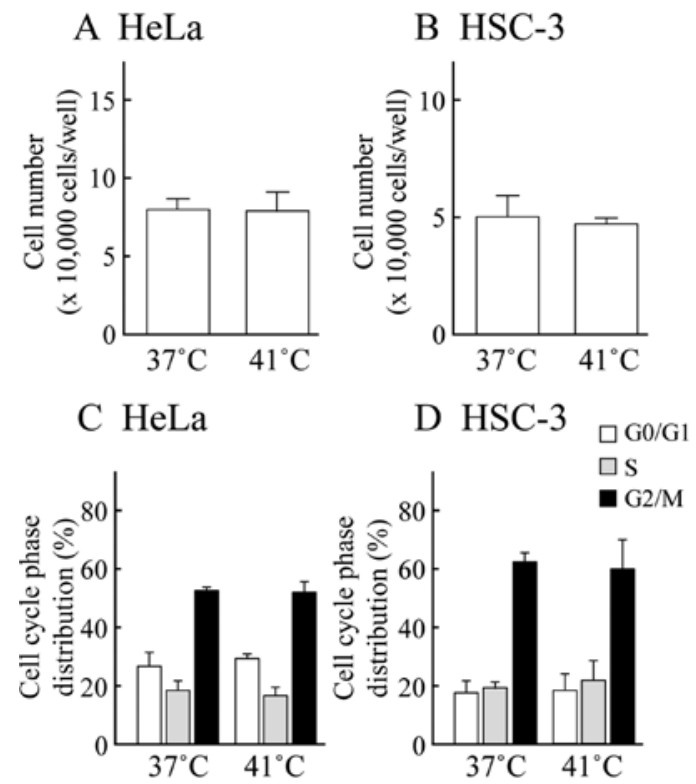

Figure 1. Effects of mild hyperthermia (MHT) on cell viability and the cell cycle in HeLa and HSC-3 cells. The cells were incubated at $37^{\circ} \mathrm{C}$ (control) or $41^{\circ} \mathrm{C}$ (MTH) for $30 \mathrm{~min}$ and then cultured at $37^{\circ} \mathrm{C}$ for $24 \mathrm{~h}$. (A and B) The cell viability and (C and D) cell cycle were analyzed. (A and C) HeLa cells. (B and D) HSC-3 cells. Data are presented as the means \pm SD $(n=4)$. regulated genes in the HeLa and HSC-3 cells exposed to MHT, respectively (Table II). The top three biological functions in each group are summarized in Table II. Biological functions including cell death and survival, gene expression and cellular function and maintenance, were observed in the upregulated genes in both cell lines, and the most prominent functions of commonly upregulated genes were cellular functions and maintenance (48 genes), as well as cell death and survival (60 genes). In the downregulated genes in both cell lines, biological functions including cell cycle, gene expression and cell death and survival were observed. The specific biological functions were cell cycle (13 genes) and cell death and survival (18 genes) in commonly downregulated genes (Table II). Furthermore, we identified two significant gene networks, A and B, that were obtained from commonly upregulated genes in both cell lines (Figs. 3 and 4). Gene network A included several HSPs, such as HSPA1A/B, heat shock $70 \mathrm{kDa}$ protein 1-like (HSPA1L), heat shock protein 4 like (HSPA4L), HSPA6, heat shock $27 \mathrm{kDa}$ protein 1 (HSPB1), HSPH1, DNAJB1, and DnaJ (Hsp40) homolog, subfamily B, member 4 (DNAJB4), as well as BAG3, and was associated with the biological functions of cellular function and maintenance (Fig. 3). Gene network B included ten genes: BCL6, basic helix-loop-helix family, member e40 


\section{HeLa}

1,754

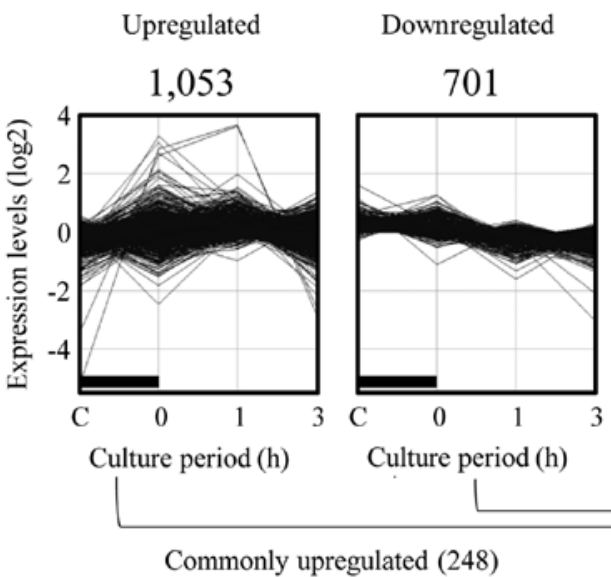

Commonly upregulated (248)

\section{HSC-3}

1,951

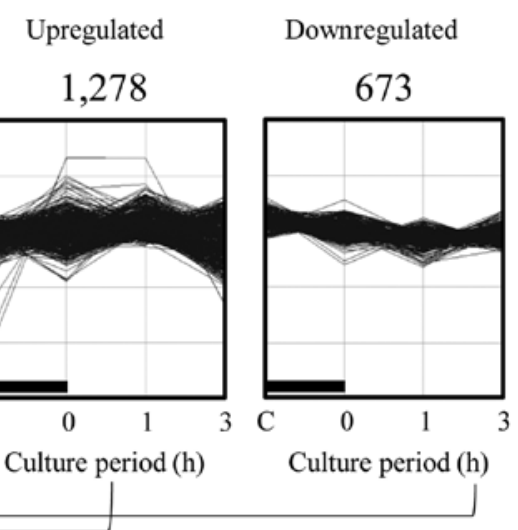

Commonly downregulated (52)

: Heat treatment

$\left(41^{\circ} \mathrm{C}, 30 \mathrm{~min}\right)$

Figure 2. Global-scale gene expression analysis. HeLa and HSC-3 cells were incubated at $41^{\circ} \mathrm{C}$ for 30 min and then cultured at $37^{\circ} \mathrm{C}$ for $0-3 \mathrm{~h}$. Gene expression analysis was performed using a GeneChip ${ }^{\circledR}$ microarray system and GeneSpring ${ }^{\circledR}$ software. The expression patterns of upregulated and downregulated probe sets in both cell lines are presented. Each number of probe sets is shown.

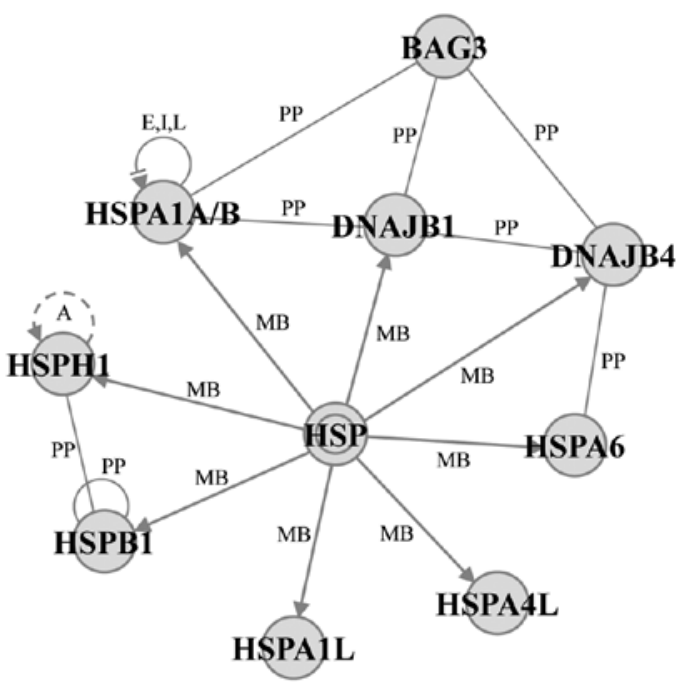

Edge labels

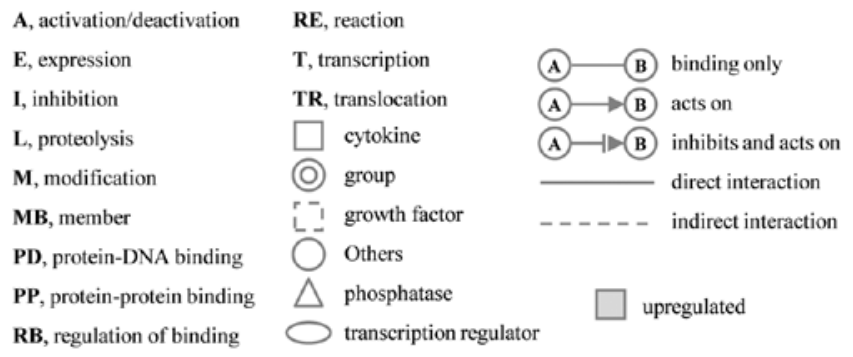

Figure 3. Gene network A. Commonly upregulated probe sets for the mild hyperthermia (MHT) conditions were analyzed by the Ingenuity Pathways Analysis software. The network is shown graphically as nodes (genes) and edges (the biological associations between the nodes).

(BHLHE40), BMP2, CTGF, dual specificity phosphatase 1 (DUSP1), EDN1, EGR1, MXD1, SOCS3 and SRY (sex deter-

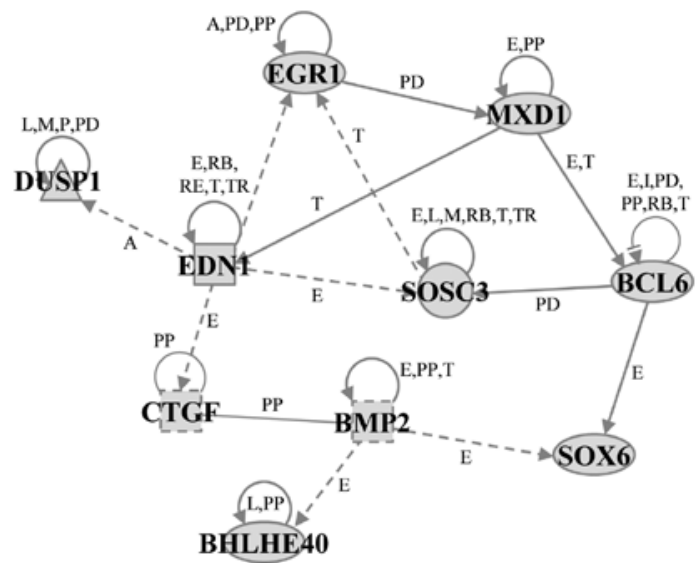

Figure 4. Gene network B. Commonly upregulated probe sets for the mild hyperthermia (MHT) conditions were analyzed by the Ingenuity Pathways Analysis software. The network is shown graphically as nodes (genes) and edges (the biological associations between the nodes). For edge labels, see Fig. 3.

mining region Y)-box 6 (SOX6) and was associated with the biological functions of cell death and survival (Fig. 4).

Verification of differentially expressed genes by real-time $q P C R$. To verify the alterations analyzed by the GeneChip microarray system, we used two cancer cell lines, MCF-7 and $\mathrm{HO}-1-\mathrm{N}-1$, in addition to the HeLa and HSC-3 cell lines. Time-dependent changes in the expression levels of selected genes that belonged to gene network A or B were measured using real-time qPCR. Among the genes in gene network A, the expression levels of HSPA1A/B, HSPA6, HSPH1, DNAJB1 and BAG3 were markedly elevated immediately following exposure to MHT in all four cell lines. The expression levels of BCL6, BMP2, CTGF, EDN1 and MXD1 in gene network B were significantly increased at $1 \mathrm{~h}$ following exposure to MHT in all four cell lines. The expression levels of EGR1 and SOCS3 

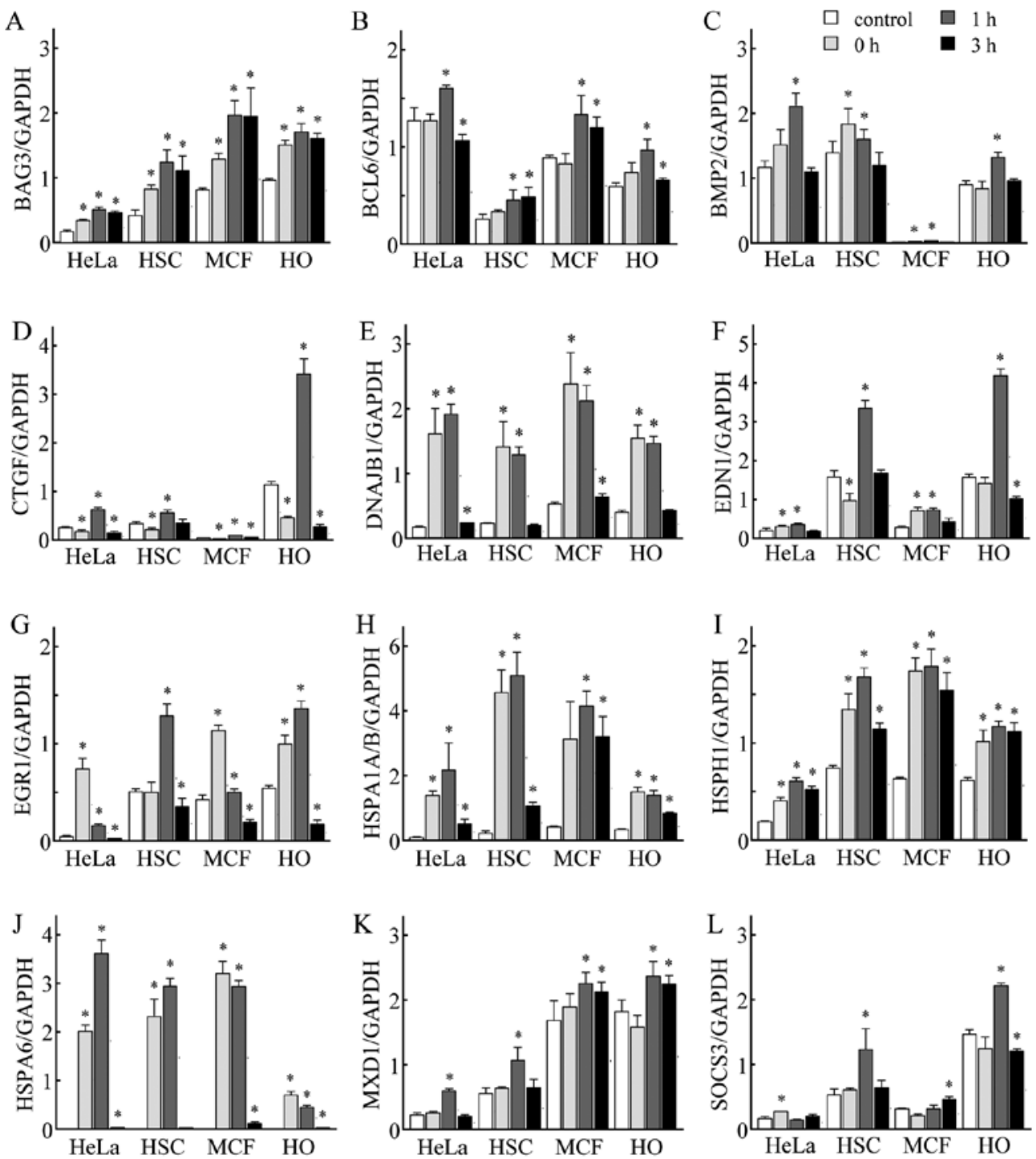

Figure 5. Verification of GeneChip ${ }^{\circledR}$ microarray results by real-time quantitative polymerase chain reaction (qPCR). The cancer cell lines, HeLa, HSC-3 (HSC), MCF-7 (MCF) and HO-1-N-1 (HO), were incubated at $41^{\circ} \mathrm{C}$ for 30 min and then cultured at $37^{\circ} \mathrm{C}$ for 0,1 and $3 \mathrm{~h}$. Real-time qPCR was performed. (A) BCL2-associated athanogene 3 (BAG3), (B) B-cell CLL/lymphoma 6 (BCL6), (C) bone morphogenetic protein 2 (BMP2), (D) connective tissue growth factor (CTGF), (E) DnaJ (Hsp40) homolog, subfamily B, member 1 (DNAJB1), (F) endothelin 1 (EDN1), (G) early growth response 1 (EGR1), (H) heat shock $70 \mathrm{kDa}$ protein 1A/B (HSPA1A/B), (I) HSPH1, (J) heat shock $70 \mathrm{kDa}$ protein 6 (HSP70B') (HSPA6), (K) MAX dimerization protein 1 (MXD1) and (L) suppressor of cytokine signaling 3 (SOCS3). Each expression level was normalized to the glyceraldehyde-3-phosphate dehydrogenase (GAPDH) expression level. Data are presented as the means $\pm S D(n=3-4)$. ${ }^{*} P<0.05$ vs. control (non-treated cells).

were significantly increased at 0,1 and $3 \mathrm{~h}$ following exposure to MHT in all four cell lines. These results are in very close agreement with those of the GeneChip ${ }^{\circledR}$ analysis with the HeLa and HSC-3 cells (Fig. 5).

\section{Discussion}

HT is a well-established treatment modality that is used alone or in combination with radiotherapy and/or chemotherapy for the treatment of a variety of tumors (1). However, due to the complexity of the heat stress signal transduction, the elucidation of the molecular mechanisms involved in the cellular responses to heat stress has remained a major challenge in studies of HT. In this study, we used global-scale microarray analysis, in conjunction with bioinformatics tools, and identified unique common gene networks in response to MHT in cancer cells.
It is well known that a temperature of $42.5^{\circ} \mathrm{C}$ for cancer cells is the inflection point of HT. That is, cancer cells exposed to temperatures $>42.5^{\circ} \mathrm{C}$ undergo cell death; however, the exposure of cells to a temperature of up to $42.5^{\circ} \mathrm{C}$ induces little or no cytotoxicity (2). In the present study, the exposure of HeLa and HSC-3 human SCC cells to MHT at $41^{\circ} \mathrm{C}$, below the inflection point, did not affect cell viability or the cell cycle, as has also been shown in our previous studies (24-27). By contrast, several genes that were upregulated or downregulated by $\geq 1.5$-fold were identified in both cancer cell lines following exposure to MHT. These results were comparable to those from previous studies on MHT conditions using cancer or normal cell lines (17,23-27). Previous studies have indicated that heat induces a significant decrease in mRNA and protein synthesis in order to increase the transcription of heat-responsive genes, such as HSPs, and that this overall reprogramming of gene expression permits the selective synthesis of HSPs $(31,32)$. 
Therefore, in this study, we focused on the common and upregulated genes elicited by MHT. We successfully identified two significant gene networks, A and B, derived from commonly upregulated genes in HeLa and HSC-3 cells exposed to MHT. In addition, the expression levels of 12 out of 19 genes selected were increased in the four cancer cell lines. Gene network A included several HSPs, as well as BAG3, and was specifically associated with the biological functions of cellular function and maintenance. Several microarray studies have demonstrated that the induction of HSPs is a common response to heat stress with or without cell death (15-27). HSPs protect cells both by limiting the effects of protein-damaging agents through protein chaperoning and refolding and by directly blocking the pathway of cell death, such as apoptosis or necrosis (12). In gene network A, HSPA1A/B (33,34), HSPB1 (35), HSPH1 (36) and DNAJB1 (33) were found to be associated with cytoprotection. BAG3 is a family of co-chaperons that interact with Hsp70 (37,38). The interaction between BAG3 and DNAJB1 or DNAJB4 has also been observed in human cells (39). The siRNA-mediated inhibition of BAG3 expression has been shown to increase apoptosis, indicating that BAG3 plays a role in the prevention of cell death $(37,38)$.

Furthermore, Ingenuity Pathway Analysis allowed us to identify the significant gene network $\mathrm{B}$, which was associated with the biological functions of cell death and survival. Seven genes in network B, BCL6 (40), BMP2 (41), CTGF (42), EDN1 (43), EGR1 (44), MXD1 (45) and SOCS3 (46), have been described as anti-cell death molecules in several types of cells, including cancer cells. Of note, we elucidated the interactions among the genes in gene network B: that is, EDN1 is involved in the upregulation of mRNAs for EGR1 (47), CTGF (48) and SOCS3 (49). It has also been reported that the binding of MXD1 DNA and EGR1 protein (50), as well as the protein-protein interaction between CTGF and BMP2 (51), occur in mammalian cells. Genes having cytoprotective or anti-cell death activity in gene networks A and B may play a role in protecting cancer cells from MHT stress.

Although HT is an important modality in cancer treatment, the acquisition of thermoresistance in cancer cells due to the elevation of HSPs makes HT less effective $(13,14)$. The induction of HSPs is regulated mainly at the transcriptional level by the activation of heat shock transcription factor 1 (HSF1) $(52,53)$. In addition, the induction of BAG3 is mediated, at least in part, by the activation of HSF1, as in the case of HSPs (54). Of note, the inhibition of the functions of HSF1 (55-57) or Hsp70 (58) by the use of gene targeting has been shown to sensitize HT-induced cell death in cancer cells. The targeting of heat shock response pathways, including these molecules in combination with HT may become a promising therapeutic approach for the treatment of cancer. In this study, we identified two gene networks comprising of several cytoprotective genes in four cancer cell lines exposed to MHT. Thus, the findings presented in this study may prove useful towards the design of more effective therapeutic strategies involving MHT or HT for the treatment of cancer.

\section{Acknowledgements}

The present study was supported in part by a Grant-in-Aid for Challenging Exploratory Research (23650303) from the Japan
Society for the Promotion of Science, and by research grants from the University of Toyama.

\section{References}

1. Hall EJ: Hyperthermia. In: Radiobiology for the Radiologist. 5th edition. Hall EJ (ed.). Lippincott Williams \& Wilkins, pp495-520, 2000.

2. Dewey WC: Arrhenius relationships from the molecule and cell to the clinic. Int J Hyperthermia 25: 3-20, 2009.

3. van der Zee J, González González D, van Rhoon GC, van Dijk JD, van Putten WL and Hart AA: Comparison of radiotherapy alone with radiotherapy plus hyperthermia in locally advanced pelvic tumours: a prospective, randomised, multicentre trial. Dutch Deep Hyperthermia Group. Lancet 355: 1119-1125, 2000.

4. Wust P, Hildebrandt B, Sreenivasa G, et al: Hyperthermia in combined treatment of cancer. Lancet Oncol 3: 487-497, 2002.

5. Issels RD: Hyperthermia adds to chemotherapy. Eur J Cancer 44: 2546-2554, 2008.

6. Issels RD, Lindner LH, Verweij J, et al: Neo-adjuvant chemotherapy alone or with regional hyperthermia for localised high-risk soft-tissue sarcoma: a randomised phase 3 multicentre study. Lancet Oncol 11: 561-570, 2010.

7. Westermann A, Mella O, Van Der Zee J, et al: Long-term survival data of triple modality treatment of stage IIB-III-IVA cervical cancer with the combination of radiotherapy, chemotherapy and hyperthermia - an update. Int J Hyperthermia 28: 549-553, 2012.

8. Beachy SH, Repasky EA: Toward establishment of temperature thresholds for immunological impact of heat exposure in humans. Int J Hyperthermia 27: 344-352, 2011.

9. Frey B, Weiss EM, Rubner Y, et al: Old and new facts about hyperthermia-induced modulations of the immune system. Int J Hyperthermia 28: 528-542, 2012.

10. Lindquist S: The heat-shock response. Annu Rev Biochem 55: 1151-1191, 1986.

11. Richter K, Haslbeck M and Buchner J: The heat shock response: life on the verge of death. Mol Cell 40: 253-266, 2010.

12. Beere HM: 'The stress of dying': the role of heat shock proteins in the regulation of apoptosis. J Cell Sci 117: 2641-2651, 2004.

13. Li GC and Werb Z: Correlation between synthesis of heat shock proteins and development of thermotolerance in Chinese hamster fibroblasts. Proc Natl Acad Sci USA 79: 3218-3222, 1982.

14. Nollen EA, Brunsting JF, Roelofsen H, Weber LA and Kampinga HH: In vivo chaperone activity of heat shock protein 70 and thermotolerance. Mol Cell Biol 19: 2069-2079, 1999.

15. Dinh HK, Zhao B, Schuschereba ST, Merrill G and Bowman PD: Gene expression profiling of the response to thermal injury in human cells. Physiol Genomics 7: 3-13, 2001.

16. Sonna LA, Gaffin SL, Pratt RE, Cullivan ML, Angel KC and Lilly CM: Effect of acute heat shock on gene expression by human peripheral blood mononuclear cells. J Appl Physiol 92: 2208-2220, 2002.

17. Murray JI, Whitfield ML, Trinklein ND, Myers RM, Brown PO and Botstein D: Diverse and specific gene expression responses to stresses in cultured human cells. Mol Biol Cell 15: 2361-2374, 2004.

18. Zhou M, Zhang A, Lin B, Liu J and Xu LX: Study of heat shock response of human umbilical vein endothelial cells (HUVECs) using cDNA microarray. Int J Hyperthermia 23: 225-258, 2007.

19. Wong HR, Odoms K and Sakthivel B: Divergence of canonical danger signals: the genome-level expression patterns of human mononuclear cells subjected to heat shock or lipopolysaccharide. BMC Immunol 9: 24, 2008.

20. Narita N, Noda I, Ohtsubo T, et al: Analysis of heat-shock related gene expression in head-and-neck cancer using cDNA arrays. Int J Radiat Oncol Biol Phys 53: 190-196, 2002.

21. Kato N, Kobayashi T and Honda H: Screening of stress enhancer based on analysis of gene expression profiles: enhancement of hyperthermia-induced tumor necrosis by an MMP-3 inhibitor. Cancer Sci 94: 644-649, 2003.

22. Borkamo ED, Dahl O, Bruland O and Fluge O: Global gene expression analyses reveal changes in biological processes after hyperthermia in a rat glioma model. Int $\mathbf{J}$ Hyperthermia 24: 425-441, 2008.

23. Laramie JM, Chung TP, Brownstein B, Stormo GD and Cobb JP: Transcriptional profiles of human epithelial cells in response to heat: computational evidence for novel heat shock proteins. Shock 29: 623-630, 2008. 
24. Tabuchi Y, Takasaki I, Wada S, et al: Genes and genetic networks responsive to mild hyperthermia in human lymphoma U937 cells. Int J Hyperthermia 24: 613-622, 2008.

25. Furusawa Y, Tabuchi Y, Wada S, Takasaki I, Ohtsuka K and Kondo T: Identification of biological functions and gene networks regulated by heat stress in U937 human lymphoma cells. Int J Mol Med 28: 143-151, 2011.

26. Tabuchi Y, Wada S, Furusawa Y, Ohtsuka K and Kondo T: Gene networks related to the cell death elicited by hyperthermia in human oral squamous cell carcinoma HSC-3 cells. Int J Mol Med 29: 380-386, 2012

27. Tabuchi Y, Furusawa Y, Kariya A, Wada S, Ohtsuka K and Kondo T: Common gene expression patterns responsive to mild temperature hyperthermia in normal human fibroblastic cells. Int J Hyperthermia 29: 38-50, 2013.

28. Furusawa Y, Iizumi T, Fujiwara Y, et al: Inhibition of checkpoint kinase 1 abrogates $\mathrm{G} 2 / \mathrm{M}$ checkpoint activation and promotes apoptosis under heat stress. Apoptosis 17: 102-112, 2012.

29. Tabuchi Y, Takasaki I, Doi T, Ishii Y, Sakai H and Kondo T: Genetic networks responsive to sodium butyrate in colonic epithelial cells. FEBS Lett 580: 3035-3041, 2006.

30. Ahmed K, Furusawa Y, Tabuchi Y, et al: Chemical inducers of heat shock proteins derived from medicinal plants and cytoprotective genes response. Int J Hyperthermia 28: 1-8, 2012.

31. Mariner PD, Walters RD, Espinoza CA, et al: Human Alu RNA is a modular transacting repressor of mRNA transcription during heat shock. Mol Cell 29: 499-509, 2008.

32. Spriggs KA, Bushell M and Willis AE: Translational regulation of gene expression during conditions of cell stress. Mol Cell 40 : 228-237, 2010

33. Zhou H, Li SH and Li XJ: Chaperone suppression of cellular toxicity of huntingtin is independent of polyglutamine aggregation. J Biol Chem 276: 48417-48424, 2001.

34. Hageman J, van Waarde MA, Zylicz A, Walerych D and Kampinga HH: The diverse members of the mammalian HSP70 machine show distinct chaperone-like activities. Biochem J 435 127-142, 2011

35. Lee YJ, Lee DH, Cho CK, et al: HSP25 inhibits radiation-induced apoptosis through reduction of PKCdelta-mediated ROS production. Oncogene 24: 3715-3725, 2005.

36. Yamagishi N, Goto K, Nakagawa S, Saito Y and Hatayama T: Hsp105 reduces the protein aggregation and cytotoxicity by expanded-polyglutamine proteins through the induction of Hsp70. Exp Cell Res 316: 2424-2433, 2010.

37. Rosati A, Ammirante M, Gentilella A, et al: Apoptosis inhibition in cancer cells: a novel molecular pathway that involves BAG3 protein. Int J Biochem Cell Biol 39: 1337-1342, 2007.

38. Jacobs AT and Marnett LJ: HSF1-mediated BAG3 expression attenuates apoptosis in 4-hydroxynonenal-treated colon cancer cells via stabilization of anti-apoptotic Bcl-2 proteins. J Biol Chem 284: 9176-9183, 2009.

39. Behrends C, Sowa ME, Gygi SP and Harper JW: Network organization of the human autophagy system. Nature 466: 68-76, 2010.

40. Kumagai T, Miki T, Kikuchi M, et al: The proto-oncogene Bc16 inhibits apoptotic cell death in differentiation-induced mouse myogenic cells. Oncogene 18: 467-475, 1999.

41. Chen S, Guttridge DC, Tang E, Shi S, Guan K and Wang CY: Suppression of tumor necrosis factor-mediated apoptosis by nuclear factor kappaB-independent bone morphogenetic protein/Smad signaling. J Biol Chem 276: 39259-39263, 2001.
42. Wang MY, Chen PS, Prakash E, et al: Connective tissue growth factor confers drug resistance in breast cancer through concomitant up-regulation of Bcl-xL and cIAP1. Cancer Res 69: $3482-3491,2009$

43. Raymond MN, Bole-Feysot C, Banno Y, Tanfin Z and Robin P. Endothelin-1 inhibits apoptosis through a sphingosine kinase 1-dependent mechanism in uterine leiomyoma ELT3 cells. Endocrinology 147: 5873-5882, 2006.

44. Weisz L, Zalcenstein A, Stambolsky P, et al: Transactivation of the EGR1 gene contributes to mutant p53 gain of function. Cancer Res 64: 8318-8327, 2004.

45. Lüscher B: Function and regulation of the transcription factors of the Myc/Max/Mad network. Gene 277: 1-14, 2001.

46. Puhr M, Santer FR, Neuwirt H, et al: Down-regulation of suppressor of cytokine signaling-3 causes prostate cancer cell death through activation of the extrinsic and intrinsic apoptosis pathways. Cancer Res 69: 7375-7384, 2009.

47. Bruneau BG, Piazza LA and de Bold AJ: BNP gene expression is specifically modulated by stretch and ET-1 in a new model of isolated rat atria. Am J Physiol 273: H2678-H2686, 1997.

48. Koitabashi N, Arai M, Kogure S, et al: Increased connective tissue growth factor relative to brain natriuretic peptide as a determinant of myocardial fibrosis. Hypertension 49: 1120-1127, 2007.

49. Chang HH, Huang YM, Wu CP, et al: Endothelin-1 stimulates suppressor of cytokine signaling-3 gene expression in adipocytes. Gen Comp Endocrinol 178: 450-458, 2012.

50. Virolle T, Krones-Herzig A, Baron V, De Gregorio G, Adamson ED and Mercola D: Egrl promotes growth and survival of prostate cancer cells. Identification of novel Egrl target genes. J Biol Chem 278: 11802-11810, 2003.

51. Maeda S: An impact of CCN2-BMP-2 complex upon chondrocyte biology: evoking a signalling pathway bypasses ERK and Smads?. J Biochem 150: 219-221, 2011.

52. Morimoto RI: Regulation of the heat shock transcriptional response: cross talk between a family of heat shock factors, molecular chaperones, and negative regulators. Genes Dev 12: 3788-3796, 1998.

53. Akerfelt M, Morimoto RI and Sistonen L: Heat shock factors: integrators of cell stress, development and lifespan. Nat Rev Mol Cell Biol 11: 545-555, 2010

54. Franceschelli S, Rosati A, Lerose R, De Nicola S, Turco MC and Pascale M: Bag3 gene expression is regulated by heat shock factor 1. J Cell Physiol 215: 575-577, 2008.

55. Rossi A, Ciafrè S, Balsamo M, Pierimarchi P and Santoro MG: Targeting the heat shock factor 1 by RNA interference: a potent tool to enhance hyperthermochemotherapy efficacy in cervical cancer. Cancer Res 66: 7678-7685, 2006.

56. Nakamura Y, Fujimoto M, Hayashida N, Takii R, Nakai A and Muto M: Silencing HSF1 by short hairpin RNA decreases cell proliferation and enhances sensitivity to hyperthermia in human melanoma cell lines. J Dermatol Sci 60: 187-192, 2010.

57. Tabuchi Y, Furusawa Y, Wada S, Ohtsuka K and Kondo T: Silencing heat shock transcription factor 1 using small interfering RNA enhances mild hyperthermia and hyperthermia sensitivity in human oral squamous cell carcinoma cells. Thermal Med 27: 99-108, 2011.

58. Gabai VL, Budagova KR and Sherman MY: Increased expression of the major heat shock protein Hsp72 in human prostate carcinoma cells is dispensable for their viability but confers resistance to a variety of anticancer agents. Oncogene 24 : $3328-3338,2005$ 